University of Nebraska - Lincoln

DigitalCommons@University of Nebraska - Lincoln

\title{
Autoseparation Method for Harvesting House Fly (Diptera: Muscidae) Pupae of Known Age
}

Jerome Hogsette

USDA-ARS, Medical and Veterinary Entomology Research Laboratory, Jerry.Hogsette@ars.usda.gov

Follow this and additional works at: https://digitalcommons.unl.edu/usdaarsfacpub

Part of the Agricultural Science Commons

Hogsette, Jerome, "Autoseparation Method for Harvesting House Fly (Diptera: Muscidae) Pupae of Known Age" (1992). Publications from USDA-ARS / UNL Faculty. 1003.

https://digitalcommons.unl.edu/usdaarsfacpub/1003

This Article is brought to you for free and open access by the U.S. Department of Agriculture: Agricultural Research Service, Lincoln, Nebraska at DigitalCommons@University of Nebraska - Lincoln. It has been accepted for inclusion in Publications from USDA-ARS / UNL Faculty by an authorized administrator of DigitalCommons@University of Nebraska - Lincoln. 


\title{
Autoseparation Method for Harvesting House Fly (Diptera: Muscidae) Pupae of Known Age
}

\author{
JEROME A. HOGSETTE \\ USDA-ARS, Medical and Veterinary Entomology Research Laboratory, P.O. Box 14565, \\ Gainesville, FL 32604
}

\begin{abstract}
J. Econ. Entomol. 85(6): 2295-2297 (1992)
ABSTRACT Postfeeding larvae of Musca domestica (L.) were allowed to crawl from the larval rearing medium into sand-filled collection containers to pupate. By separating postfeeding larvae and pupae from the sand at predetermined intervals, the approximate time of pupation and the pupal age could be determined. More postfeeding larvae were collected in fine, wet sand than in coarse, dryer sand. Whether or not the sand was tightly packed into collection containers was unimportant, and fly mortality was not increased by the sand-collection method. Uses for the system and implications of the results are discussed.
\end{abstract}

KEY WORDS Musca domestica, pupae, known age

FOR ALMOST EVERY aspect of research involving the hymenopterous pupal parasites of muscoid flies, high-quality muscoid fly pupae of known age are an indispensable requirement. Pupae are necessary for the maintenance of parasite colonies in the laboratory (Morgan 1986) and for sampling indigenous parasite populations in the field (Merchant et al. 1985, Smith \& Rutz 1991). Despite their importance, techniques for production of pupae of known age have not been published. Use of pupae of known age is casually stated in most publications as though the technique used and its attributes and limitations are common knowledge (e.g., Gerling \& Legner 1968; Morgan et al. 1975, 1978, 1981; Coats 1976; Legner 1989; Smith \& Rutz 1991).

Methods routinely used for separating muscoid fly pupae from growth media such as flotation (Bridges et al. 1984, Morgan 1986), forced air (Goodhue \& Linnard 1950, Bailey 1970), and autoseparation (Pickens \& Lorenzen 1983), may limit the time during which pupae can be used successfully by the parasites. For instance, pupae generally do not float until after the completion of larval-pupal apolysis (Fraenkel \& Bhaskaran 1973); therefore, many pupae $<24 \mathrm{~h}$ old will be lost if the flotation method is used. Endoparasites such as Trichopria stomoxydis (Huggert) best use pupae which are $<24 \mathrm{~h}$ old (Morgan et al. 1990), but gathering ample numbers of pupae in this narrow age range that are

This article reports the results of research only. Mention of a commercial or proprietary product does not constitute an endorsement or a recommendation for its use by USDA. free of growth medium can be time consuming. If puparia are allowed to tan completely before being separated from the growth media, age can be estimated with enough accuracy for routine production of ectoparasites (Morgan 1986). However, improved results might be obtained if the actual pupation time could be estimated more accurately.

The objective of this study was to develop a simple method for harvesting large numbers of pupae of known age, preferably one in which postfeeding larvae would migrate out of the growth medium and pupate in a second medium.

\section{Materials and Methods}

Fine, sugar sand (70-140 mesh) and coarse, sandblasting sand (30-65 mesh) were used as substrates for postfeeding larvae (Fraenkel \& Bhaskaran 1973) to crawl into and pupate. Wet and dry sand treatments were prepared volumetrically; they consisted of 3.2 and $5.3 \mathrm{ml}$ of sand, respectively, per $1 \mathrm{ml}$ of water. Collection containers were fabricated from $240-\mathrm{ml}$ clear plastic specimen cups (10 cm high) from which the bottoms had been removed and replaced with standard 16-mesh window screen. The sand-water mixtures were placed in collection containers and either lightly packed or firmly packed. For the lightly packed condition, the sand-water mixture was added to the collection containers with no intentional packing, leaving some small pockets unoccupied by sand. For the firmly packed condition, the sand-water mixture 
was tightly packed with a spoon as it was added to the collection containers.

The Gainesville House Fly Diet (Hogsette 1992) was measured into larval rearing trays (50 by 40 by $10 \mathrm{~cm}$ ) (Morgan 1986), moistened with water at a ratio of $1: 1$ by volume, and seeded with $\approx 30,000$ house fly, Musca domestica (L)., eggs $<6 \mathrm{~h}$ old. Trays were kept in the larval rearing room, which was maintained at $26.7^{\circ} \mathrm{C}$ with $60 \% \mathrm{RH}$. To collect postfeeding larvae, collection containers filled with $\approx 240 \mathrm{ml}$ of the sand-water mixtures were placed on the surface of the larval medium in the corners of the rearing trays at the rate of four per tray. The screened bottoms of the collection containers were pressed gently $\approx 1-2 \mathrm{~cm}$ into the larval medium, allowing larvae to enter the collection containers by crawling in through the screen. Placement of collection containers was made $72 \mathrm{~h}$ after eggs were added to the growth medium, and after postfeeding larvae began moving toward the corners of the trays. Collection containers remained in the larval trays for $24 \mathrm{~h}$. Meanwhile, a second identical set of containers was prepared and held in reserve.

After all collection containers were removed from the larval trays, one container was immersed in an upright position in a pan of water. This caused the sand to drop immediately through the screened bottom of the container, leaving the immature flies behind. As quickly as the collection container was lifted from the water, it was placed on top of a container from the second set with the same sand-water-packing specifications. This procedure allowed any mobile larvae in the first container to crawl down through the screen into the sand in the second container. All containers were processed in this manner. After $24 \mathrm{~h}$ more, this process was repeated (i.e., containers from the second set were immersed and placed on prepared containers in a third set). Collection containers were kept in the rearing room except during processing.

The statistical design was a 2 by 2 by 2 factorial, with two types of sand, two levels of moisture, and two degrees of packing (eight treatments). Treatments were placed randomly in the corners of two larval rearing trays on each of 3 consecutive d (i.e., three replications). Adult emergence from pupae collected in sand was compared with that of control pupae from the same trays. Control pupae (100 per larval rearing tray per day) were selected at random after pupae in larval rearing trays had been harvested by flotation (Morgan 1986) and dried in a forced-air dryer (Bailey 1970).

Data were analyzed with general linear model procedures, and Tukey's studentized range test (SAS Institute 1985) was used for separation of means. Unless otherwise stated, $P=0.05$.
Table 1. Main effects means for pupae collected in two sand types with two moisture levels and two degrees of packing

\begin{tabular}{|c|c|c|c|c|}
\hline $\begin{array}{c}\text { Day } \\
(n=8)\end{array}$ & $\begin{array}{l}\text { Sand type } \\
(n=12)\end{array}$ & $\begin{array}{c}\text { Moisture } \\
\text { level } \\
(n=12)\end{array}$ & \multicolumn{2}{|c|}{$\begin{array}{c}\text { Degree of } \\
\text { packing } \\
(n=12)\end{array}$} \\
\hline $178 \mathrm{~b}$ & Fine $320 a$ & Wet $302 \mathrm{a}$ & Light & $265 a$ \\
\hline $333 a$ & Coarse $184 \mathrm{~b}$ & Dry 20lb & Firm & $238 a$ \\
\hline $245 \mathrm{ab}$ & - & - & & \\
\hline
\end{tabular}

Means followed by the same letter are not significantly different ( $P=0.05$, Tukey's studentized range test [SAS Institute 1985]).

\section{Results and Discussion}

Pupae separated from the fine, sugar sand significantly outnumbered the number of pupae separated from the coarse, sandblasting sand, and significantly more pupae were recovered from the sand with the higher moisture level (Table 1). The degree of packing did not affect the number of pupae recovered, but daily collections differed significantly. The largest number of pupae collected in a single container during $24 \mathrm{~h}$ was 595 . Differences in adult eclosion from floated pupae and those collected from sand were not significant; eclosion in both groups was $\geq 97.7 \%$.

When the three original sets of collection containers were retrieved from the larval trays and the sand was removed, 6,038 larvae were recovered. These larvae quickly crawled down through the screen and into the sand in the second set of collection containers. Only eight individuals, all collected on day 1 of each replication, had developed to the white prepupa stage. These prepupae, all $<4 \mathrm{~h}$ old (Fraenkel \& Bhaskaran 1973), were retained in their original collection containers. When the sand was washed from the second set of collection containers $24 \mathrm{~h}$ later, all individuals had advanced past the white prepupal stage, and their puparia were in various stages of the tanning process. These pupae were all $<24 \mathrm{~h}$ old. No mortality of postfeeding larvae was observed in the collection containers.

It was surprising that larvae preferred the fine, sugar sand because this sand packed easily and appeared to be more difficult to penetrate than the course sand. However, the degree of packing of either sand type was unimportant (Table 1). The sand with the higher water content attracted $\approx 50 \%$ more postfeeding larvae than the dryer sand. The recovery of more larvae from the wetter sand is particularly interesting when my results are compared with the system of Pickens \& Lorenzen (1983), in which larvae were allowed to crawl from the growth medium and pupate in dry sand.

The numbers of individuals collected on different collection dates were significant, but this was probably a result of day-to-day variation in 
the colony. House fly eggs routinely are collected and used on the same day. However, eggs collected on the current day are frequently mixed with eggs saved from the previous day; this could cause a slight variation in larval development rates.

Larval trays are seeded with $\approx 30,000$ house fly eggs. However, the size of the collection containers limited the number of larvae recovered to $\approx 1,200$ per day per tray. Recovery could be greatly increased by use of larger collection containers, especially ones with larger screencovered openings. Containers used for these studies had a screened area of $\approx 16 \mathrm{~cm}^{2}$. Once inside the collection containers, larvae compacted and displaced the sand further, thus causing concern about increased pupal mortality from cuticular abrasion. However, this was not reflected by any difference in adult eclosion between the sand and control groups.

In this study, pupae were extracted at 24-h intervals. However, these intervals could be changed to accommodate the design of a particular project. Shorter intervals obviously will result in the collection of pupae with closely synchronized development times. Pupae collected by the sand method can be used as sentinel pupae in field projects, although it has been suggested-but not substantiated-that chemical cues used by parasites for host detection may be removed when pupae are processed in water (Petersen et al. 1983).

\section{Acknowledgment}

I thank F. Washington and G. Langley, USDA-ARS, Gainesville, FL, for their technical assistance in this study.

\section{References Cited}

Bailey, D. L. 1970. Forced air for separating pupae of house flies from rearing medium. I. Econ. Entomol. 63: 331-333.

Bridges, A. C., J. W. Summerlin \& G. E. Spates. 1984. $A$ new and more economical base medium for rearing larvae of the stable fly, horn fly, and house fly. Southwest. Entomol. 9: 388-390.

Coats, S. A. 1976. Life cycle and behavior of Muscidifurax zaraptor (Hymenoptera: Pteromalidae). Ann. Entomol. Soc. Am. 69: 772-80.

Fraenkel, G. \& G. Bhaskaran. 1973. Pupariation and pupation in cychlorrhaphous flies (Diptera): terminology and interpretation. Ann. Entomol. Soc. Am. 66: 418-422

Gerling, D. \& E. F. Legner. 1968. Developmental history and reproduction of Spalangia cameroni, parasite of synanthropic flies. Ann. Entomol. Soc. Am. 61: 1436-1443.
Goodhue, L. D. \& C. E. Linnard. 1950. An air separation apparatus for cleaning fly pupae. J. Econ. Entomol. 43: 228.

Hogsette, J. A. 1992. New diets for production of house flies and stable flies (Diptera: Muscidae) in the laboratory. J. Econ. Entomol. 85: 2291-2294.

Legner, E. F. 1989. Fly parasitic wasp, Muscidifurax raptorellus Kogan \& Legner (Hymenoptera: Pteromalidae) invigorated through insemination by males of different races. Bull. Soc. Vector Ecol. 14: 291-300.

Merchant, M. E., R. V. Flanders \& R. E. Williams. 1985. Sampling method comparisons for estimation of parasitism of Musca domestica (Diptera: Muscidae) pupae in accumulated poultry manure. J. Econ. Entomol. 78: 1299-1303.

Morgan, P. B. 1986. Mass culturing microhymenopteran pupal parasites (Hymenoptera: Pteromalidae) of filth breeding flies, pp. 77-87. In R. S. Patterson \& D. A. Rutz [eds.], Biological control of muscoid Hies. Entomol. Soc. Am. Misc. Pub. No. 61. Lanham, MD.

Morgan, P. B., R. S. Patterson, G. C. LaBrecque, D. E. Weidhaas, A. Benton \& T. Whitfield. 1975. Rearing and release of the house fly pupal parasite, Spalangia endius Walker. Environ. Entomol. 4: 609-611.

Morgan, P. B., D. E. Weidhaas \& G. C. LaBrecque. 1978. Host-parasite relationship of the house $\mathrm{fly}$, Musca domestica L., and the microhymenopteran parasite, Pachycrepoideus vindemiae (Rondani). Southwest. Entomol. 3: 176-181.

Morgan, P. B., D. E. Weidhaas \& R. S. Patterson. 1981. Programmed releases of Spalangia endius and Muscidifurax raptor (Hymenoptera: Pteromalidae) against estimated populations of Musca domestica (Diptera: Muscidae). I. Med. Entomol. 18: $158-166$

Morgan, P. B., J. A. Hogsette \& R. S. Patterson. 1990. Life history of Trichopria stomoxydis (Hy. menoptera: Proctotrupoidea: Diapriidae) a gregarious endoparasite of Stomoxys calcitrans from Zimbabwe, Africa. Fla. Entomol. 73: 496-502.

Petersen, J. J., J. A. Meyer, D. A. Stage \& P. B. Morgan. 1983. Evaluation of sequential releases of Spalangia endius (Hymenoptera: Pteromalidae) for control of house flies and stable flies (Diptera: Muscidae) associated with confined livestock in eastern Nebraska. I. Econ. Entomol. 76: 283-286.

Pickens, L. G. \& K. J. Lorenzen. 1983. A new larval diet for Musca domestica (Diptera: Muscidae). J. Med. Entomol. 20: 572-573.

SAS Institute. 1985. SAS user's guide: statistics. SAS Institute, Cary, NC.

Smith, L. \& D. A. Rutz. 1991. Relationship of microhabitat to incidence of house fly (Diptera: Muscidae) immatures and their parasitoids at dairy farms in central New York. Environ. Entomol. 20: 669-674.

Received for publication 13 April 1992; accepted 29 July 1992. 